Artikel

\title{
STRATEGI MENGUASAI MATERI AJAR \\ DALAM PERKULIAHAN MICRO TEACHING PADA MAHASISWA JURUSAN SOSIOLOGI FIS UNP
}

\author{
Oleh: Junaidi, S.Pd., M.Si
}

\begin{abstract}
ABSTRAK
Pada pertama kali tampil mengajar, sangat sedikit mahasiswa peserta perkuliahan Micro Teaching Jurusan Sosiologi UNP yang mampu menguasai materi ajar, namun setelah diberikan pengarahan setiap selesai tampil maka mereka bisa berubah. Pada penampilan terakhir, hampir semua mahasiswa bisa menguasai materi ajar dengan baik. Tujuan penelitian ini adalah ingin mengetahui bagaimana strategi mahasiswa menguasai materi ajar tersebut.

Penelitian ini menggunakan pendekatan kualitatif, dengan pemilihan informan melalui teknik purposive sampling. Data dikumpulkan dengan menggunakan teknik wawancara, pengamatan, dan dokumentasi, yang dianalisis secara interaktif memalui tahap reduksi data, penyajian data, dan penarikan kesimpulan.

Hasil penelitian mengungkapkan bahwa ada lima macam strategi yang dilakukan mahasiswa dalam menguasai materi ajar, yaitu (1) kombinasi sumber belajar, (2) mencari poin penting, (3) mengasosiasi contoh, (4) membuat catatan kecil, dan (5) memilih waktu dan suasana hening.
\end{abstract}

Kata-kata kunci: strategi, menguasai, materi ajar.

\section{A. Pendahuluan}

Penguasaan materi ajar merupakan kemampuan esensial yang harus dimiliki oleh seorang mahasiswa calon guru yang sedang mengukuti perkuliahan Micro Teaching, karena sangat berpengaruh terhadap pembelajaran. Apabila 
mahasiswa telah mampu menguasai materi ajar maka kegiatan pembelajaran akan berjalan dengan lancar serta sistematis, sebaliknya apabila mahasiswa tidak menguasai materi ajar maka kegiatan pembelajaran akan mengambang dan tanpa arah. Seterusnya, mahasiswa yang menguasai materi ajar akan dapat dengan mudah mencapai tujuan pembelajaran, sedangkan mahasiswa yang tidak menguasai akan kesulitan untuk mencapai tujuan pembelajaran.

Sebelum mahasiswa tampil, dosen pembina memberikan pengarahan tentang pentingnya penguasaan materi ajar, namun pada penampilan pertama sangat sedikit (kira-kira 20\%) mahasiswa yang tidak menguasai materi ajar. Pada penampilan kedua, jumlah mahasiswa meningkat hingga 40-50\%. Setelah selalu diberikan pengarahan, maka pada penampilan ketiga, terjadi peningkatan yang cukup berarti, yaitu 90-95\% sudah menguasai materi dengan baik.

Fenomena di atas menarik penulis untuk melakukan penelitian mengenai strategi mereka dalam menguasai materi ajar. Tulisan ini akan mendeskripsikan tentang strategi mahasiswa menguasai materi ajar dalam mengikuti perkulihan Micro Teaching di Jurusan FIS UNP. Untuk membahas permasalahan ini penulis menggunakan Teori Pemrosesan Informasi. Teori ini merupakan bagian dari Teori Kognitivistik. Teori Pemrosesan Informasi memfokuskan perhatian pada bagaimana orang memperhatikan peristiwa-peristiwa lingkungan, mengkodekan informasi-informasi untuk dipelajari, dan menghubungkannya dengan pengetahuan yang ada dalam memori, menyimpan pengetahuan yang baru dalam memori, dan menariknya kembali ketika dibutuhkan. 


\section{B. Metode Penelitian}

Penelitian ini merupakan penelitian deskriptif dengan tipe kualitatif, karena mengkaji mahasiswa dalam kaitannya dengan strategi mereka dalam mengausai materi ajar, yang berlokasi di Jurusan Sosiologi FIS UNP. Informan dipilih dengan teknik purposive sampling. Informan penelitian adalah mahsiswa Jurusan Sosiolgi FIS UNP yang telah tercatat sebagai peserta perkuliahan Micro Taching pada semester Juli - Desember 2014. Setelah penelitian, terkumpullah sebanyak 15 informan.

Pengumpulan data dilakukan dengan menggunakan teknik wawancara secara terbuka dan mendalam. Kegiatan ini dilakukan pada hari Rabu tanggal 22, 29 Oktober, dan 5 Nopember 2014. Guna mendukung data dari hasil wawancara, juga dilakukan teknik observasi atau pengamatan. Selain wawancara dan observasi, penelitian ini juga menggunakan teknik dokumentasi yang diperoleh dari arsip dan dokumen-dokumen yang ada di Jurusan Sosiologi FIS UNP Padang.

Data yang telah diperoleh diuji keabsahannya melalui teknik triangulasi sumber dan triangulasi teknis. Selanjutnya dianalisis dengan menggunakan model interactive analysis seperti yang dikembangkan oleh Miles dan Huberman, yakni melalui tahap-tahap reduksi data, display data dan pengambilan keputusan.

\section{Hasil Peneilitian dan Pembahasan}

Berdasarkan hasil pengumpulan data, ada beberapa strategi yang dilakukan oleh mahasiswa untuk menguasai materi ajar dalam mengikuti perkuliahan Micro Teaching di Jurusan sosiologi FIS UNP, yaitu sebagai berikut: 
1. Mengkombinasikan sumber belajar. Langkah pertama yang dilakukan oleh mahasiswa adalah menyiapkan sumber belajar (learning resource). Mahasiswa peserta Micro Teaching mempersiapkan sumber belajar dari beberapa sumber. Mereka menyiapkan rata-rata dua sumber belajar. Dengan adanya bebarapa sumber, lalu mengkombinasikannya, mereka dapat menemukan titik-titik temu atau kesamaan informasi dari materi yang akan mereka kuasai. Dengan demikian, keyakinan akan kebenaran informasi untuk materi ajar semakin kuat. Dalam mempersiapkan sumber, mahasiswa juga mempertimbangkan waktu antara 1-2 minggu sebelum tampil. Keputusan mengkombinasikan sumber belajat dan memilih waktu mempersiapkan materi ajar dilakukan mahasiswa atas pertimbangan yang sesuai dengan kondisi dan kemampuan dirinya. Hal ini sesuai dengan penjelasan Teori Pemrosesan Informasi yang menerangkan bahwa Tingkat pemrosesan stimulus informasi diproses dalam berbagai tingkat kedalaman secara bersamaan bergantung kepada karakternya. Semakin dalam suatu informasi diolah, maka informasi tersebut akan semakin lama diingat.

2. Mencari poin penting. Setelah sumber belajar diperoleh, maka selanjutnya mahasiswa membaca sumber tersebut dengan cara mencari poin-poin penting atau kata-kata kunci. Poin-poin penting itu lalu dicatat secara khusus untuk dipahami. Hal ini mereka lakukan terhadap semua sumber belajar baik buku teks, buku paket peserta didik, maupun sumber dari internet. Pada saat membaca, mereka lakukan berulang-ulang kali. Ketika sekali atau dua kali baca mereka belum mendapatkan poin pegangan, 
sehingga harus diulang lagi. Mereka membaca hingga tiga kali, bahkan lebih sehingga akhirnya menemukan poin-poin penting materi. Materi yang dibaca untuk dikuasai dengan cara seperti itu adalah terutama berupa materi ajar prinsip dan prosedur. Apa yang dilakukan oleh mahasiswa tersebut sesuai dengan Teori Pemrosesan Informasi, yang menjelaskan bahwa penerimaan informasi dalam diri manusia dimulai dari menangkap informasi dari lingkungan melalui organ-organ sensorisnya yaitu: mata, telinga, hidung, lidah, dan kulit. Beberapa informasi disaring pada tingkat sensoris, kemudian sisanya dimasukkan dalam ingatan jangka pendek. Ingatan jangka pendek mempunyai kapasitas pemeliharaan informasi yang terbatas sehingga kandungannya harus diproses secara sedemikian rupa (misalnya dengan pengulangan atau pelatihan), jika tidak maka akan lenyap dengan cepat.

3. Mengasosiasi contoh, adalah upaya memahami dengan mengambil contoh yang ada di dalam buku sumber lalu mencari kesamaannya dengan kejadian nyata yang dekat dengan lingkungan sendiri, sehingga diperoleh pemahaman yang utuh terhadap materi yang dibaca. Tanpa contoh, maka materi yang dipahami bisa tidak sesuai dengan maksud dari isi materi yang disajikan dalam sumber belajar. Apa yang dilakukan oleh mahasiswa itu dapat dijelaskan melalaui Teori Pemrosesan Informasi bahwa mahasiswa secara aktif memproses informasi dan pembelajaran berlangsung melalui usaha-usaha subjek ketika mahasiswa yang bersangkutan mengaturnya, menyimpannya dan kemudian menemukan hubungan-hubungan antara 
informasi. Contoh-contoh yang ada di dalam buku sumber harus diasosiasikan dengan fakta atau contoh nyata yang ada di sekitar mahasiswa. Semakin dalam suatu informasi diolah, maka informasi tersebut akan semakin lama diingat. Sebagai contoh, informasi yang mempunyai imajinasi visual yang kuat atau banyak berasosiasi dengan pengetahuan yang telah ada akan diproses secara lebih dalam. Demikian juga informasi yang sedang diamati akan lebih dalam diproses dari pada stimuli atau kejadian lain di luar pengamatan. Dengan kata lain, mahasiswa akan lebih mengingat hal-hal yang mempunyai arti bagi dirinya atau hal-hal yamg menjadi perhatiannya karena hal-hal tersebut diproses secara lebih mendalam dari pada stimuli yang tidak mempunyai arti atau tidak menjadi perhatiannya. Materi yang dikuasai dengan cara pemahaman ini adalah berupa materi fakta dan konsep.

4. Membuat catatan kecil. Catatan kecil dibuat setelah mahasiswa membaca sumber terlebih dahulu. Caranya adalah dengan menemukan kalimat inti, lalu ditulis sendiri ke dalam catatan pendek. Penulisan apa yang dibaca ke dalam catatan kecil memberikan kemudahan bagi mahasiswa untuk menguasai materi ajar. Di samping menuliskan kembali ke dalam bentuk yang sederhana, para mahasiswa juga mencatatnya dengan menggunakan bahasa sendiri. Mereka berusaha mencari cara lain, dan tidak mengikuti bahasa atau kalimat persis yang ada di buku sumber. Prinsip strategi atau cara seperti itu sangat mempengaruhi beban memori belajar. Beban yang sederhana lebih mudah dan cepat diterima oleh memori mahasiswa. Hal 
ini sesuai dengan pernyataan isi Teori Pemrosesan Informasi, bahwa proses pengolahan informasi dalam ingatan dimulai dari proses penyandian informasi (encoding), diikuti dengan penyimpanan informasi (storage), dan diakhiri dengan mengungkapkan kembali informasiinformasi yang telah disimpan dalam ingatan (retrieval). Ingatan terdiri dari struktur informasi yang terorganisasi dan proses penelusuran bergerak secara hirarkhis, dari informasi yang paling umum dan inklusif ke informasi yang paling umum dan rinci, sampai informasi yang diinginkan diperoleh. Teori di atas menjelaskan bahwa dalam usaha memahamai dan menguasi materi perlu dilakukan penyandian informasi atau encoding, yakni mengubah informasi atau bacaan ke dalam bentuk lain yang sederhana dan mudah untuk dipahami.

5. Memilih waktu dan suasana yang hening. Mereka menghindari suasana yang riuh dan ramai. Waktu dan suasana tertentu sangat mempengaruhi meraka untuk dapat menguasai materi ajar. Suasana pada pukul tiga pagi tersebut sangat hening, dan kondisi pikiran juga sedang segar, sehingga materi lebih mudah dan cepat dikuasai. Pemilihan waktu dan suasana yang hening sebagai strategi untuk menguasai materi oleh para mahasiswa di atas dapat dipahami secara teoritis dan bersifat logis. Hal ini dapat diterangkan melalui Teori Pemrosesan Informasi yang menjelaskan bahwa dalam pemrosesan informasi terjadi adanya interaksi antara kondisikondisi internal dan kondisi eksternal individu. Kondisi internal yaitu keadaan dalam diri individu yang diperlukan untuk mencapai hasil belajar 
dan proses kognitif yang terjadi dalam individu. Sedangkan kondisi eksternal adalah rangsangan dari lingkungan yang mempengaruhi individu dalam proses pembelajaran. Interaksi yang terjadi pada mahasiswa adalah kondisi internal mahasiswa berupa kesiapan memorinya untuk menerima informasi bahan ajar dari bacaan. Interkasi hanya akan terjadi jika suasana eksternal mendukung untuk itu. Suasana yang mendukung adalah keadaan yang sepi atau hening. Dengan suasana yang hening memori lebih terbuka dan siap menerima informasi yang dibaca oleh mahasiswa. Selain itu, strategi ini juga akan memberikan tingkat penguasaan yang lebih dalam dan bertahan lama, karena informasi yang dibaca diperoleh melalui tahapan prosedur yang sempurna. Hal ini sesuai dengan penjelasan dari Teori Pemrosesan Informasi bahwa manusia menangkap informasi dari lingkungan melalui organ-organ sensorisnya yaitu: mata, telinga, hidung, lidah, dan kulit. Beberapa informasi disaring pada tingkat sensoris, kemudian sisanya dimasukkan dalam ingatan jangka pendek. Ingatan jangka pendek mempunyai kapasitas pemeliharaan informasi yang terbatas sehingga kandungannya harus diproses secara sedemikian rupa (misalnya dengan pengulangan atau pelatihan), jika tidak maka akan lenyap dengan cepat. Bila diproses, informasi dari ingatan jangka pendek dapat ditransfer ke dalam ingatan jangka panjang. Ingatan jangka panjang merupakan hal penting dalam proses belajar. 


\section{Penutup}

Berdasarkan hasil penelitian dan pembahasan, dapat diambil kesimpulan bahwa ada lima macam strategi penguasaan materi ajar pada mahasiswa Jurusan Sosiologi FIS UNP. Pertama, mengkombinasikan sumber materi. Dengan sumber materi yang lebih dari satu mahasiswa dapat menemukan titik temu informasi dari beberapa sumber. Kedua, mencari poin penting atau kata-kata kunci dari materi ajar. Ketiga, mengasosiasi contoh yang terdapat di dalam materi ajar atau sumber materi diaosiasikan (dicari kesamaan karakternya) dengan contoh nyata yang terdapat di lingkungan sekitar, maka tingkat pemahaman dan penguasaan materi ajar akan semakin tinggi. Keempat, membuat catatan kecilsehingga meringankan mahasiswa untuk menghapal dan sekali gus menguasai materi ajar yang dibaca. Kelima, memilih waktu dan suasan yang hening. Semakin hening suasana dan tempat membaca, maka semakin cepat materi ajar dipahamai dan dikuasai oleh mahasiswa.

Di sini, penulis juga memberikan beberapa saran sebagai berikut:

1. Beberapa mahasiswa lebih menomorsatukan buku paket peserta didik sebagai sumber materi. Sikap seperti ini sebaiknya tidak salah, namun sebaiknya mahasiswa calaon guru mengutamakan buku teks, karena tingkat kebenaran dan kedalaman serta keluasan buku teks lebih baik dibanding buku paket.

2. Dalam silabus sosiologi terdapat materi tentang penelitian sosial sederhana. Sebagian besar mahasiswa menyatakan mengalami kesulitan untuk memahami dan membelajarkan materi tersebut. Berdasarkan hal itu, disarankan kepada 
pihak lain untuk melakukan penelitian secara khusus mengenai kesulitan yang dialami oleh mahasiswa.

\section{Daftar Pustaka}

E. Mulyasa. 2006. Kurikulum Tingkat Satuan Pendidikan. Bandung: PT. Remaja Rosdakarya.

Hergenhahn, B.R dan Olson, Mattew H. 2010. Theories of Learning. Jakarta: Prenada.

Muhammad Ali. 2004. Guru Dalam Proses Belajar Mengajar. Bandung: Sinar Baru Algensindo.

Masnur Muslich. 2008. KTSP Dasar Pemahaman dan Pengembangan. Jakarta: Bumi Aksara.

Miles, Mathew B. And Huberman, A Michael. 1986. Qualitative Data Analysis. Baverly Hills: Sage Publications, Inc.

S. B. Djamarah. 1994. Prestasi Belajar dan Kompetensi Guru. Surabaya: Usaha Nasional.

S. Nasution. 1996. Metodologi Penelitian Naturalistik Kualitatif. Bandung: Tarsito.

Smith, Mark K. 2009. Teori Pembelajaran dan Pengajaran. Jogjakarta: Mirza Media Pustaka

Wina Sanjaya. 2010. Perencanaan dan Desain Sistem Pembelajaran. Jakarta: Kencana. . 2011. Strategi Pembelajaran Berbasis Standar Proses pendidikan. Jakarta: Kencana 


\begin{abstract}
At first appeared teaching, very few students participating in lectures Micro Teaching Sociology Department UNP were able to master the teaching material, but after briefed each finished performing then they can change. In recent appearances, almost all students can master the teaching materials well. The purpose of this study was to find out how the students strategies to master the teaching materials.

This study used a qualitative approach, with the election of informants through purposive sampling technique. Data collected by using interviews, observation and documentation, which analyzed interactively memalui stage data reduction, data presentation, and conclusion.

Results of the study revealed that there are five kinds of strategies in which students in mastering teaching materials, namely (1) a combination of learning resources, (2) look for the important points, (3) associates example, (4) make little notes, and (5) pick a time and there was silence.
\end{abstract}

Key words: strategy, control, teaching materials. 